\title{
Cultural Guidelines for Commercial Production of Purple Passion Plant (Gynura aurantiaca) ${ }^{1}$
}

Jianjun Chen and Richard J. Henny ${ }^{2}$

Gynura belongs to the family Compositae and comprises about 50 species indigenous to the humid tropics of Africa, Malaysia, China, Vietnam, and Thailand. Gynura was first described in 1838. A few species are produced as interiorscape plants due to their colorful velvety foliage. The species most commonly cultivated commercially in Florida is Gynura aurantiaca, whose green leaves and vining stems are densely covered with short, vividly purple hairs. This fuzzy texture adorns the plant in a rich, colorful glow and gives rise to common names: purple velvet plant and purple passion plant. It is easily grown in hanging baskets or as small-containerized potted foliage. This article is intended to provide guidelines for the commercial production of purple passion plant (Gynura aurantiaca) including propagation, cultural requirements, common problems and recommendations for interior use.

\section{Cultivars of Gynura Aurantiaca}

There are two cultivars in production: one commonly called purple passion or the purple velvet plant (Fig. 1) and the other is the variegated purple passion plant (Fig. 2).

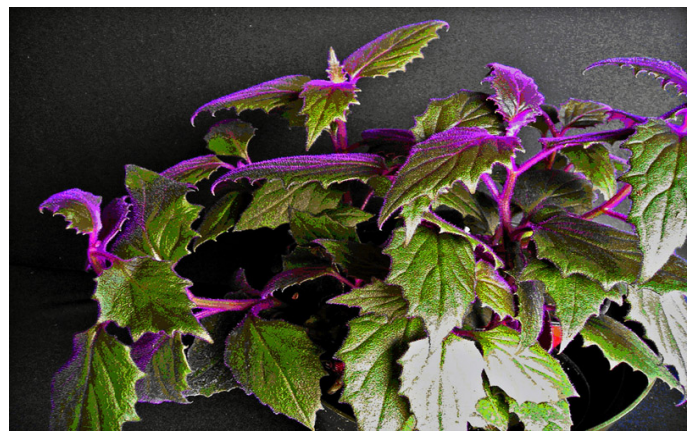

Figure 1. Green leaves and vining stems of purple passion (Gynura aurantiaca) are densely covered in vividly purple hairs.

In spring and early summer in Florida, purple passion produces clusters of small, yellow-orange flowers. Generally, scented flowers on plants are desirable and improve marketability. But flowers produced by purple passion plant have a fragrance obnoxious enough to be offensive. Additionally, given appropriate light conditions, water and fertilizer, purple passion plants will grow very quickly and thus may acquire a leggy appearance. To

1. This document is ENH1079, one of a series of the Environmental Horticulture Department, Florida Cooperative Extension Service, Institute of Food and Agricultural Sciences, University of Florida. Original publication date October, 2007. Visit the EDIS Web Site at http://edis.ifas.ufl.edu.

2. J. Chen is an associate professor and R. J. Henny is a professor at the University of Florida Institute of Food and Agricultural Sciences Mid-Florida Research and Education Center, Apopka, Department of Environmental Horticulture, University of Florida, Gainesville, 32611.

The use of trade names in this publication is solely for the purpose of providing specific information. UF/IFAS does not guarantee or warranty the products named, and references to them in this publication does not signify our approval to the exclusion of other products of suitable composition.

The Institute of Food and Agricultural Sciences (IFAS) is an Equal Opportunity Institution authorized to provide research, educational information and other services only to individuals and institutions that function with non-discrimination with respect to race, creed, color, religion, age, disability, sex, sexual orientation, marital status, national origin, political opinions or affiliations. U.S. Department of Agriculture, Cooperative Extension Service, University of Florida, IFAS, Florida A. \& M. University Cooperative Extension Program, and Boards of County Commissioners Cooperating. Larry Arrington, Dean 


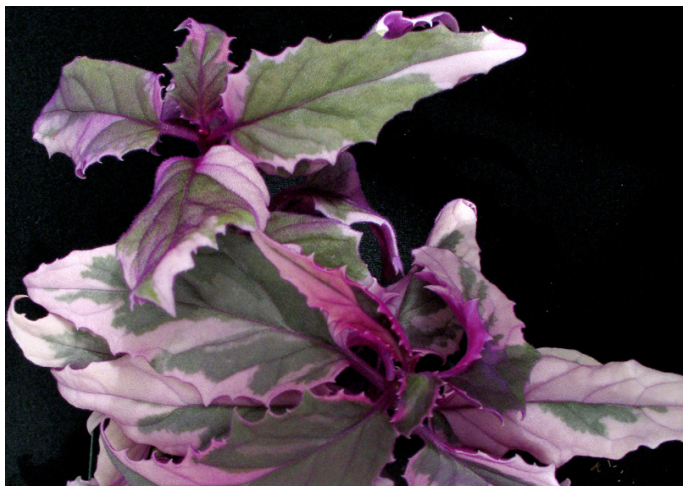

Figure 2. Green and white leaves of variegated purple passion cultivar (Gynura aurantiaca) are also densely hairy.

make this plant more aesthetically appealing, flowering must be inhibited and creeping growth habit should be controlled.

\section{Cultural Guides}

\section{Propagation}

Purple passion is easily propagated by stem cuttings. Cuttings may be taken at any time and will root year round if provided with sufficient warmth and humidity. Single or double node cuttings are stuck into medium-filled cells of plug trays or multiple cuttings are stuck directly into the growing medium in the finish pots or hanging baskets. Rooting is best accomplished in media containing $50 \%$ peat, $25 \%$ bark, and $25 \%$ perlite by volume with $\mathrm{pH} 5.5$ to 6.0 . Roots will form in one to two weeks if a minimum media temperature of $75^{\circ} \mathrm{F}$ and proper media moisture are maintained. Use of rooting hormones may improve root initiation and production timing but is not a requisite. Gynura roots are fibrous and delicate, and care must be taken to maintain even medium moisture at all times. However, the root zone should not become saturated since this favors development of root rot diseases.

\section{Production}

Multiple cuttings should be potted into 4-inch, 6-inch, or 8-inch pots or hanging baskets if rooted in cell plugs. Plants should be grown in a shaded greenhouse or shadehouse under 2000 to 3000 foot candles and temperatures between 60 to $90^{\circ} \mathrm{F}$. The best temperature range for growth is 75 to $85^{\circ} \mathrm{F}$. Growth reduction may occur if day temperatures are at or below $60^{\circ} \mathrm{F}$. When the day temperatures exceed $80^{\circ} \mathrm{F}$, Gynura grows rapidly and may become leggy. Growing media should be kept moist but not over-watered. Controlled-release fertilizers or water-soluble fertilizers, or a combination of both, can be used for purple passion production. A fertilizer with an $\mathrm{N}-\mathrm{P}_{2} \mathrm{O}_{5}-\mathrm{K}_{2} \mathrm{O}$ ratio of 3:1:3 is recommended because purple passion requires more potassium. The suggested application rate is $2.5 \mathrm{lb} \mathrm{N}$ per 1,000 sq. ft. per month. Growers should monitor the $\mathrm{pH}$ and the nutrient status of potting media by checking soluble salts levels at least monthly using $\mathrm{pH}$ and electrical conductivity (EC) meters. Media solution can easily be extracted by the pour-through method. If EC readings fall below $1.0 \mathrm{dS} / \mathrm{m}$, additional fertilization is needed; whereas if EC readings are above $3.0 \mathrm{dS} / \mathrm{m}$, growers should reduce either the frequency or amount of applied fertilizer. Table 1 provides a guide for determining appropriate fertilization for purple passion based on leaf analysis.

\section{Growth and Flowering Control}

As mentioned previously, Gynura flowers are malodorous. Flowering coupled with an over-grown leggy appearance have been key limitations in its production and use in interiorscaping. Traditionally, flower buds and leggy growth have been controlled by manually pinching and pruning.

Research at the Mid-Florida Research and Education Center (MREC) was conducted to determine the effects of growth regulators on controlling growth and flowering in purple passion (Chen et al., 2002). A-Rest (ancymidol), B-Nine (daminozide), Bonzi (paclobutrazol), cycocel (chlormequat chloride), and florel (ethephon), were each diluted to three different concentrations and sprayed in two applications in early spring at two-week intervals. Results, presented in Table 2, indicated that applications of A-Rest ${ }^{\circledR}$, B-Nine ${ }^{\circledR}$, Bonzi ${ }^{\circledR}$ and $\mathrm{Cycocel}{ }^{\circledR}$, regardless of treatment concentrations, were ineffective in 
suppressing the flowering of purple passion, whereas Florel ${ }^{\circledR}$ completely suppressed flowering at the three concentrations used $(250,500$, and 1,000 ppm). Plants treated with Florel ${ }^{\circledR}$ grew more lateral shoots, which produced a compact and dense bush-look, indicating that appropriate concentrations of Florel ${ }^{\circledR}$ application not only stopped flowering of purple passion but also improved and prolonged its aesthetic value as a potted or hanging-basket plant.

\section{Acclimatization, Shipping, and Interior Care}

Acclimatization is suggested to condition purple passion for better interior performance.

Acclimatization is a stepped procedure in which light intensity, nutrient supply, and irrigation frequency are gradually reduced (Chen et al., 2005). The acclimatization process anatomically and physiologically slows the plant so it will survive and even thrive after placement in an interior environment. One month before shipping, light intensity should be reduced to low, or 1000 to 1500 foot candles. Irrigation frequency should be reduced to keep the potting medium barely moist, and fertilizer application should be reduced or ceased 30 days before plants are shipped.

Shipping sleeves are needed for transporting large hanging-basket purple passion to reduce breakage of the vines. Recommended temperature range for shipping is 55 to $60^{\circ} \mathrm{F}$ as exposure to a temperature below $55^{\circ} \mathrm{F}$ may cause chilling injury. Irrigate the medium thoroughly the day before shipping to reduce stress during transportation.

Acclimatized purple passion tolerates an interior light level as low as 150 foot candles; but optimal light levels range from 150 to 250 foot candles. Plants maintain their aesthetic appearance better if relative humidity is kept between 40 and $60 \%$. Allow the surface of the potting medium to dry slightly before watering. Periodically check the EC of the potting medium using the pour-through method. Keep EC reading below $1.5 \mathrm{dS} / \mathrm{m}$. If EC readings are below
$1.0 \mathrm{dS} / \mathrm{m}$, add a diluted fertilizer solution with $\mathrm{N}$ at 50 ppm monthly. Temperatures should be kept between 65 and $80^{\circ} \mathrm{F}$ indoors. To avoid straggliness and to encourage a bushy look, manually pinch off the tips of branches as they become too long.

\section{Literature Cited}

Jianjun Chen, Richard J. Henny, and Russell D. Caldwell.2002. Ethephon Suppresses Flowering and Improves the Aesthetic Value of Purple Passion Plant (Gynura aurantiaca). J. Environ. Hort. 20:228-231.

Chen, J., Q. Wang, D.B. McConnell, and R.J. Henny. 2005. Responses of tropical foliage plants to interior low light conditions. Acta Horticulturae 669:51-56. 
Table 1. Nutrient concentrations in mature leaves considered low, medium, and high for purple passion plant (Gynura aurantiaca) production.

\begin{tabular}{||l|l|l|l||}
\hline Nutrient & Low & Medium & High \\
\hline Nitrogen (\%) & $<3.0$ & $3.0-4.0$ & $>4.0$ \\
\hline Phosphorus (\%) & $<0.5$ & $0.5-0.8$ & $>0.8$ \\
\hline Potassium (\%) & $<3.5$ & $3.5-5.5$ & $>5.5$ \\
\hline Calcium (\%) & $<1.0$ & $1.0-2.0$ & $>2.0$ \\
\hline Magnesium (\%) & $<0.5$ & $0.5-1.0$ & $>1.0$ \\
\hline Sulfur (\%) & $<0.3$ & $0.3-0.4$ & $>0.4$ \\
\hline Iron (ppm) & $<80$ & $80-160$ & $>160$ \\
\hline Manganese (ppm) & $<150$ & $150-200$ & $>200$ \\
\hline Zinc (ppm) & $<30$ & $30-50$ & $>50$ \\
\hline Copper (ppm) & $<8$ & $8-20$ & $>20$ \\
\hline Boron (ppm) & $<40$ & $40-65$ & $>65$ \\
\hline \hline
\end{tabular}

Table 2. Effect of foliar sprays of A-Rest $\Theta$, B-Nine $\AA$, Bonzi $\AA$, Cycocel $\Theta$, and Florel $\Theta$ on the average stem length, production of flowers, and overall quality of purple passion plant.

\begin{tabular}{|l|c|c|c|c|}
\hline Growth regulator & Concentration $(\mathbf{p p m})$ & Average stem length $\mathbf{( c m})$ & Flowers per plant & Quality $^{\mathbf{z}}$ \\
\hline Control $^{y}$ & 0 & 48.3 & 15.99 & 3.4 \\
\hline \multirow{3}{*}{ A-Rest } & 25 & 7.6 & 15.4 & 2.2 \\
& 75 & 6.9 & 27.8 & 2.1 \\
\hline \multirow{3}{*}{ B-Nine } & 150 & 6.3 & 6.4 & 1.8 \\
& 1250 & 35.2 & 27.8 & 3.0 \\
\hline \multirow{3}{*}{ Bonzi } & 2500 & 21.8 & 15.0 & 3.6 \\
& 5000 & 16.2 & 35.0 & 3.0 \\
\hline \multirow{3}{*}{ Cycocel } & 15 & 24.9 & 7.5 & 3.0 \\
& 50 & 6.5 & 6.5 & 1.8 \\
\hline \multirow{3}{*}{ Florel } & 100 & 6.8 & 38.3 & 3.4 \\
& 500 & 39.9 & 27.0 & 3.2 \\
\hline
\end{tabular}

${ }^{2}$ Plant quality where 1 = very poor; 2 = poor, unsaleable; 3 = fair, maybe saleable if flower occurrence was not a concern; $4=$ good quality, no flowers and compact look; and $5=$ excellent quality, no buds or flowers, compact look, and deep purple color.

${ }^{y}$ Deionized water as control. 